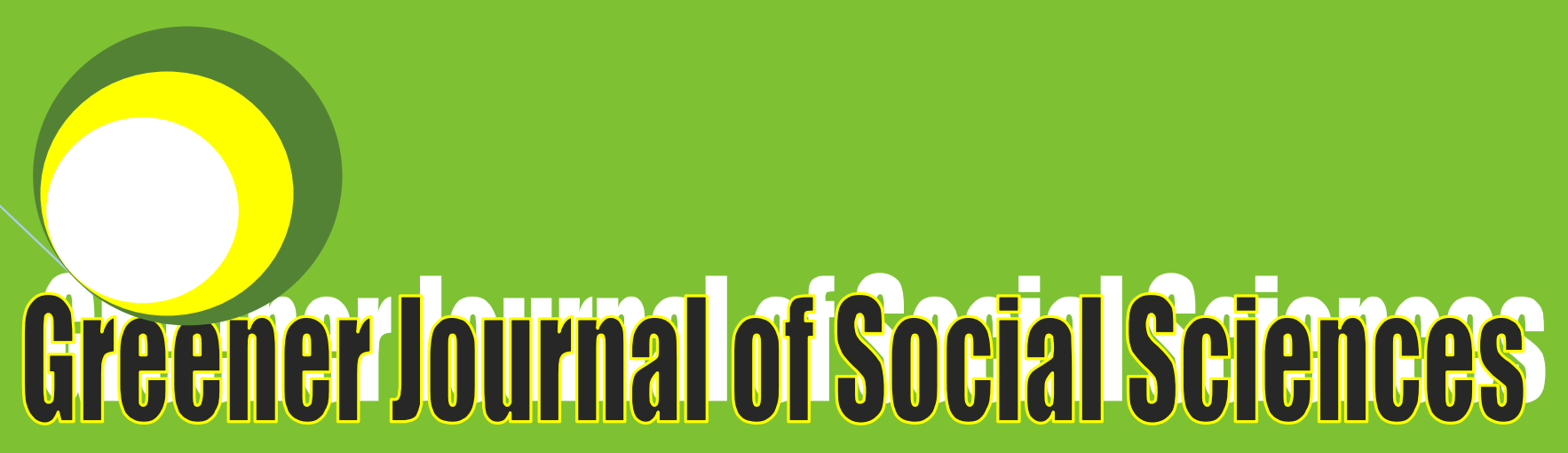

ISSN: 2276-7800 ICV: 5.99

Submitted: $22 / 08 / 2017$

Accepted: 28/08/2017

Published: 15/09/2017

\title{
Social Media Tools in \\ Education: A Case of \\ WhatsApp use by \\ Heritage Studies \\ Teachers in Zimbabwe
}

By

Dr. Kudzayi Savious Tarisayi

Ronald Manhibi 


\title{
Research Article (DOI: http://doi.org/10.15580/GJSS.2017.4.082217108)
}

\section{Social Media Tools in Education: A Case of WhatsApp use by Heritage Studies Teachers in Zimbabwe}

\section{Dr Kudzayi Savious Tarisayi ${ }^{1}$ and Ronald Manhibi ${ }^{2}$}

\author{
${ }^{1}$ School of Education, University of KwaZulu-Natal, South Africa, kudzayit@ gmail. com. +27710046019. \\ ${ }^{2}$ Head ICT, Reformed Church University, Zimbabwe, ronmanhibi@ gmail. com. +263772550389.
}

Corresponding Author's E-mail: kudzayit@ gmail.com

\begin{abstract}
An understanding of the role of WhatsApp groups as social media tools used in the delivery of change in the Zimbabwean education is still rudimentary. This study sought to assess the role played by a WhatsApp group for Heritage Studies teachers in Zimbabwe in addressing new curriculum implementation challenges. The study was guided by a symbolic interactionism theoretical framework. The lived experiences of the participants in this study were elicited through the use of a questionnaire which was administered by the researchers. The questionnaire was sent to the participants via the WhatsApp platform for Heritage Studies teachers. The study established that the WhatsApp group for Heritage Studies teachers was utilised as a vehicle for the dissemination of the new Heritage Studies Syllabus, syllabus interpretation, sharing of reading material as well as staff development. It can be concluded from this study that Zimbabwean Heritage Studies' teachers used WhatsApp groups to facilitate the implementation of the new curriculum in general and Heritage Studies syllabus in particular.
\end{abstract}

Keywords: Social media, WhatsApp, New curriculum, Heritage Studies

\section{INTRODUCTION}

This article foregrounds Heritage Studies teachers' interactions via a WhatsApp group to address new curriculum implementation challenges in Zimbabwe. Studying the interactions on the Heritage Studies teachers' WhatsApp group highlights the substantive insights of the role played by social media in the 2017 curriculum implementation in Zimbabwe. Zimbabwe's Ministry of Primary and Secondary Education (MoPSE) could potentially utilise the power of the social media tools unpacked by this study in implementing future programmes. While communication has been taking place for centuries, the way it occurs has evolved by the day. The evolution of technology can be named as one of the causes and catalysts for changes in the way of communicating. Advances in the field of Information and Communication Technologies (ICTs) have drastically changed the way people work, live, socialise, advertise, shop, teach and learn because they can perform a variety of tasks that could not be easily performed before the emergence of new technologies (Bilbao-Osorio \& Dutta, 2012). Social media is amongst some of the technological tools birthed in the twenty-first $\left(21^{\text {st }}\right)$ century used for communication and information sharing (Abaido \& El-Messiry, 2016). In the recent past a multiplicity of articles, chapters, theses and books have been written on social media especially in the wake of the Arab Spring (Shabir, Mahmood, Hameed, Safdar, Farouq \& Gilani , 2014). Resultantly a number of explanatory models on social media have emerged in discourse. Among the most vocal narratives to emerge in discourse is the political role played by social media in the Arab Spring (Ali, 2011). Furthermore, Nadvi (2017, p. 200) reveals, "Other spontaneous citizen protests, such as South Africa's \#FeesMustFall, Zimbabwe's \#ThisFlag, and the US's \#BlackLivesMatter used social media for planning and mobilisation,..... In Kenya, the \#StopPoliceBrutality movement utilised social media to encourage many people to protest. In addition, within the political narrative scholars such as Persily (2017) have interrogated the social media role in the 2016 US Presidential elections. Thus, these available narratives view social media as a political tool or platform for mobilising citizens for a cause and or to support a particular candidate in an election. Wangui (2014) offers a divergent narrative of social media use which reveals that it can be utilised positively and not for antagonism as aptly shown in Kenya. The Kenyan government utilises various forms of social media to engage citizens and to create exchange of ideas with the citizenry on enhancing social amenities and services (Wangui, 2014). However, these narratives reviewed above negate the facilitation role of social media in education as well as curriculum adoption. In addition, Mustafa, Ghani, Zumrah, Ramly, Azdi and Ahmad (2013) and Saleem, Prot, Anderson and Lemieux et al (2015) reveal the influence of social media on the lives of individual Muslims. The study by Mustafa et al (2013) on the impact of social media had 
specific reference to Facebook users in Malaysia. While another study by Ab Halim Tumari Dan Zarin Ismail revealed myriads of negative contents in the social media can result in negative impacts on its users (Mustafa et al., 2013, p. 173). Therefore, it can be argued that these social media studies have been focused on the impact of social media on Muslims without necessarily analysing the implications of education as pursued by this study. Abaido and El-Messiry (2016) studied the level of usage of WhatsApp and impact on quality of education in Dubai and established that there was an interaction of instructor-student as well as student-student. Another study by Bouhnik and Deshen (2014) on class WhatsApp groups confirmed that they were used for four main purposes: "communicating with students; nurturing the social atmosphere; creating dialogue and encouraging sharing among students; and as a learning platform". However, these studies by Abaido and El-Messiry (2016) and Bouhnik and Deshen (2014) negate communication between teachers within the same school as well as in other schools which is pursued in this paper. Moreover, it can be revealed that these studies have been carried out outside Zimbabwe and therefore there is a need for a study to be carried in Zimbabwe.

A social network is a platform that connects people based on common interests and relationships. It does this through the use of technology, which is referred to as social media. The relationship between modern social networks and social media is complex making it difficult for some scholars to separate the two when defining them. In the Cambridge online dictionary (2017), a social network is defined as "a website or computer program that allows people to communicate and share information on the internet using a computer or mobile phone". Whereas, the Oxford Online Dictionary (2017) refers to a social network as "a network or social interactions and personal relationships" and "a dedicated website or other application which enables users to communicate with each other by posting information, comments, messages and images". Scott and Jacka (2011, p. 5) cited in Sokolova, 2013, p. 5) define social media as a "set of web-based broadcast technologies that enable the democratisation of content, giving people the ability to emerge from consumers of content to publishers". According to Miller et al (cited in Haynes, 2016), "social media are those forms of communication that provide a middle ground between public broadcasting and private communication." In addition, Chen (2013) defines social media as a "way to describe a collection of online systems that allow for the production, storage and distribution of user-generated content (UGC). Social media allows for the creation of a virtual social space where groups of users can come together in synchronous and asynchronous interactions". As noted in the definitions presented above the diversity of social media makes it is very difficult to coin a concrete statement that out defines it explicitly. This study focused on WhatsApp use as a case study of social media. Sayan (2016, p. 88) avers, "WhatsApp is a Smartphone application that operates on nearly all current types of devices and operating systems". The versatility of WhatsApp which enables it to operate on many types of devices has made it a platform of choice for teachers in Zimbabwe. This has been coupled with affordable custom data packages and bundles provided by the mobile internet service providers in Zimbabwe. The custom made WhatsApp packages range from daily, weekly as well as monthly bundles. In addition, Sayan (2016, p. 89) avers, "The simple operation scheme makes the program accessible to a variety of people of different ages and backgrounds. WhatsApp enables communication with anyone who possesses a Smartphone, has an active internet connection, and has installed the application". Church and de Oliveira ((2013) cited in Chiridza, Yorodani, Sigauke, \& Katsaruware, 2016, p. 46) state, "WhatsApp is a cross-platform instant messaging application for smartphones". Furthermore, it uses the Internet to send text messages, images, videos, user location, audio messages to individuals or groups in real-time at no cost and of late, making calls (Chiridza et al., 2016). The use of WhatsApp in Zimbabwe has largely been promoted by the flooding of cheap smart phones from China and Dubai. WhatsApp use in Zimbabwe has also been necessitated by an increase in the number of Zimbabweans living in the 'diaspora'.

As noted in the definitions above social media, social networking applications and social network sites connect people who may be located in different geographical locations, which mean that they are dependent on the availability of the Internet for them to work. International Telecommunication Union (ITU) (2016b, p. 3), the official United Nations arm mandated with collecting and reporting ICT statistics globally reported that 2016 recorded "a greater ICT use than access" when compared to previous years. The ITU (2016a) 2016 facts and figures report revealed that currently (that is as at December 2016) the internet penetration rates are pegged at $81 \%$ in developed countries, $40 \%$ in developing countries and $15 \%$ in the Least Developed countries. Both ITU reports indicate the improvements noticed in the use of ICTs the world over is due to the continued reduction of ICT related products' prices. The 2016 ICT statistics also show an uneven distribution of the 185,000 Gigabits per second bandwidth that was used globally, owing to the fact that Internet access to the International backbone grid still needs to improve for developing and least developed countries (ibid). On the contrary, ITU reports of a wider mobile coverage estimated at $95 \%$ of the world population in 2016 , with only $53 \%$ of this percentage connected to the internet as advanced mobile broadband network technologies like Long Term Evolution (LTE) have been spreading quickly. Kabweza (2015) avers that about $97 \%$ of the Zimbabwean populace uses cell phones which makes Zimbabwe the second highest mobile phone users in Africa after South Africa. In addition, Kabweza (2015) also reports that Zimbabwe has 6.1 million Internet subscriptions with $99 \%$ of those being mobile device based. Thus, the Heritage Studies teachers who participated in this study are part of the 6.1 million internet subscribers in Zimbabwe. 
Surveys conducted in America over a decade (2005-2015) to systematically track adults' social media use of social networking sites revealed that social media use changed from $7 \%$ in 2005 to $65 \%$ in 2015 (Perrin, 2015). According to (ibid) adults with high levels of education and income are more likely to be regular social media users. The WhatsApp platform connected social actors (teachers), which in turn broke communication barriers that are normally associated with setting up formal forums and participants benefitted from the social network. According to a census conducted in 2012 , Zimbabwe is a landlocked country with $33 \%$ and $67 \%$ of the population located in the urban and rural areas (respectively) (ZimStat, 2013). The Government of Zimbabwe's (2015) National ICT policy notes that inadequate information communications infrastructure is one the ICT sector challenges bottlenecking the widespread of Internet services to all parts of the country. According to the statistics mentioned above the majority of the people and teachers in this particular study are located in the rural areas where Internet access is restricted to the expensive broadband mobile based connections due to the infrastructure constraints in those areas.

Texting someone through the social media platform is way cheaper compared to sending an SMS. The competition between telecommunication companies has even made it cheaper as there are predefined social media internet access packages for accessing the popular social networking sites and applications like WhatsApp and Facebook using mobile devices. According to Gambanga (2016a), 30us cents can grant a user, 20Megabytes of WhatsApp data access over a period of 24 hours in Zimbabwe. Major Zimbabwean telecommunication companies that include: TelOne, Zimbabwe Online (ZOL), Liquid Telecomms, Africom, Telecontract, Dandemutande and Powertel and Econet Wireless have setup Wireless Fidelity (Wi-Fi) hotspot zones in public urban areas like food courts and parks to improve access (Gambanga, 2016b). One of the telecommunications provider Econet Wireless recently launched a facility to boost the mobile Internet access through the installation of cheaper mobile Wireless Fidelity (Wi-Fi) in selected commuter omnibuses (Kabweza, 2017). Teachers travelling from one point to another can/could now be guaranteed of near-ubiquitous internet access on their intermittent WhatsApp capable smartphones.

The use of WhatsApp groups to disseminate information by a publishing house in Zimbabwe to Heads of Departments (HODs) for each learning area sowed the seeds for collaboration amongst teachers. The publishing house created national WhatsApp groups, comprising HODs pooled together sampling ten (10) schools in each of the ten provinces in Zimbabwe. The groups were created as a marketing strategy to get feedback from teachers on the publishing house's products. The initiative was later expanded by the participants through the creation of splinter groups. The authors of this paper participated in these WhatsApp groups for HODs and witnessed the metamorphosis of the WhatsApp groups from marketing the publishing house's books to the discussion of the examination tips towards the end of 2016. Teachers used the electronic platform to discuss past exam papers. Past examination papers and examination tips were shared amongst the teachers on the WhatsApp groups. Teachers in different parts of the country managed to bridge geographical distance through their interactions on the WhatsApp platform. Experienced teachers used the platform to share their expertise while the 'novice' teachers took the opportunity to benefit from the tips and advice of the seasoned teachers. There was free interaction among the teachers which was facilitated by the anonymity that came with the WhatsApp groups. Therefore, we argue that the WhatsApp groups which connected teachers in Zimbabwe were an avenue for mutual values and vision, helpful and communal leadership, collective learning, supportive conditions and mutual practice. The groups had powerful interactions which were very vibrant and engaging for most participants. With the adoption of the new curriculum in 2017 (Dokora, 2015; ZBC, 2017), the groups shifted their focus to the new curriculum. The implementation of the new primary and secondary education curriculum in Zimbabwe came with a number of teething challenges, which necessitated a shift in the focus of the WhatsApp groups. Some of the challenges included; teachers' realisation that the changes in the curriculum which included the introduction of new learning areas were not matched by adequate preparedness, financial constraints and the lack of textbooks in support of the curriculum's new learning areas (Murava, 2017; Nkala, 2017). Instead of teachers fault-finding the minister over the approach and timing of the introduction of the new curriculum they resorted to using WhatsApp groups to share, and the staff develop themselves on the new curriculum. New WhatsApp groups were created for the new learning areas such as Heritage Studies, Economic History, and Physical Education. This study is premised on the role played by these WhatsApp groups which we argue replaced formal staff development platforms such as subject panels.

It was against a background of a myriad of challenges bedevilling the education sector in Zimbabwe, the MoPSE initiated a curriculum review process which culminated in a new curriculum in 2017 (Pachikoro Staff, 2016). The curriculum review process witnessed the participation of various stakeholders ranging from business, teachers' colleges, polytechnic colleges, universities, uniformed forces, traditional and religious leaders as well as parents. The new curriculum introduced a new learning area known as Heritage Studies. Heritage Studies was introduced against a backdrop of the realisation that there was a dearth in the curriculum of a special focus on culture and inherited traditions. Matseketsa and Mashaah (2017) aver that the subject speaks for the past generations and preserves embodiments of the way we live and pass it on to the future generations. 


\section{THEORETICAL FRAMEWORK}

The study in pursuance of the role played by a WhatsApp group for Heritage Studies teachers enlisted the symbolic interactionism theoretical framework. Aldiabat and Navenec (2011) reveal that the symbolic interactionism theory was proffered by Mead (1863-1931) and it is based on three principles, meaning, language and thought. The symbolic interactionism theory holds that meanings are products of "process of interaction between people" (Mackinnon, 2005, p. 89). Thus, in this study meanings on the implementation of the new curriculum in general and Heritage Studies syllabus in particular stems from the interaction of Heritage Studies on the WhatsApp platform. Heritage Studies teachers are viewed as constructing meanings on the role of WhatsApp in the new curriculum implementation according to the symbolic interactionism theory.

\section{METHODOLOGY}

This study on the role played by the WhatsApp group for Heritage Studies teachers in the implementation of the new curriculum was situated in the interpretive paradigm. This entailed studying, "things in their natural settings, attempting to make sense of or to interpret phenomena in terms of the meanings people bring to them" (Denzin \& Lincoln, 2008, p. 3). The population for this study was composed of 256 Heritage Studies teachers who were participants in a WhatsApp group. The researchers utilised a questionnaire that was disseminated via the WhatsApp group and yielded a hundred responses from the Heritage Studies teachers. The findings were triangulated with observations by the researchers as participants of the group. The study followed a phenomenological research design. A phenomenological research design pronounces the meaning of several individuals of their lived experience (Hammersley, 2000) and hence, in this study described the meaning of several Heritage Studies' teachers of their lived experience with the new curriculum implementation in Zimbabwe.

\section{DISCUSSION OF FINDINGS}

Findings from this study revealed that the WhatsApp group for Heritage Studies' teachers in Zimbabwe was instrumental as a vehicle for the dissemination of the Heritage syllabus which was introduced in 2017. Ninety percent of the participants in this study acknowledged receiving their copy of the Heritage Studies syllabus via the WhatsApp group. It was further noted from this study that when schools opened for the 2017 first term, copies of the Heritage syllabus had not been received by schools from the MoPSE via the formal communication system. Hard copies of the Heritage Studies were only distributed to schools by the relevant authorities at the end of January 2017. One participant revealed, "The Heritage Studies group was a life saver as I managed to get my first copy of the Heritage Studies syllabus. I was getting desperate waiting for the hard copy to come via the formal system". Hence, we argue from this study that WhatsApp was utilised by the Heritage Studies teachers who participated in this study to disseminate the new syllabus. Therefore, this study further revealed that WhatsApp was a faster communication platform for disseminating information on the newly introduced syllabus.

In addition, the study further revealed that the WhatsApp platform was also used for syllabus interpretation by Heritage Studies teachers. One participant stated, "The ministry did not conduct syllabus interpretation workshops for the new Heritage Studies syllabus. Syllabus interpretation was done on our WhatsApp group. Teachers discussed the syllabus topics, aims and objectives of the syllabus on the WhatsApp group". Thus, instead of waiting for the ministry to conduct workshops in schools on syllabus interpretation the teachers used WhatsApp to discuss and interpret the syllabus. In addition, the WhatsApp platform provided a cheaper, fast hassle-free and cost-cutting avenue for the staff development of teachers in Zimbabwe. A number of studies have established that teacher professional development in Zimbabwe is curtailed by poor funding (Delport \& Makaye, 2009; Maphosa, Mutekwe, Machingambi, Wadesango, \& Ndofirepi, 2013; Chikoko (2005) cited in Nyandoro, Mapfumo, \& Makoni, 2013, p. 264). We noted from this study that the ministry was yet to conduct syllabus interpretation workshops in some parts of the country five months after the adoption of the new Heritage Studies syllabus. Therefore, it can be argued from this study that the loopholes in the rolling out of the new syllabus were being addressed through the use of the WhatsApp platform by Heritage Studies teachers in the district. Hence, our argument that the Heritage Studies platform for teachers in Zimbabwe was not only a vehicle for the dissemination of the new Heritage Studies Syllabus but also for the interpretation of the new Heritage Studies syllabus to a large extent.

Findings from this study further revealed that Heritage Studies teachers that participated in this study shared reading material on their WhatsApp group. Despite conventional wisdom on the importance of ensuring the availability of adequate reading material before the introduction of new subjects into the national curriculum, Heritage Studies was introduced without availing textbooks. In spite of the narrative that the new curriculum is informed by the recommendation made by the Nziramsanga educational report, it failed to take due cognisance of the observation that, "there is a tendency to introduce new subject areas without the requisite textbooks, equipment and expertise" (Nziramasanga, 1999, p. 243). Therefore, in order to overcome the reading material 
shortage challenge, the teachers who participated in this study revealed that they shared Heritage Studies reading material on their WhatsApp group. One participant revealed that "Teachers who had access to Heritage Studies lecture notes, hand-outs, textbooks as well as modules from local tertiary institutions shared with others on the WhatsApp group. Any journal article or text thought as relevant to the learning area was uploaded and shared by the group". Hence, the Heritage Studies WhatsApp group provided reading materials which filled the vacuum that had initially been created by the unavailability of textbooks in schools as highlighted in the Nziramasanga Commission report (Murava, 2017; Nkala, 2017; Nziramasanga, 1999). Thus, we argue from this study that WhatsApp was essential for Heritage Studies teachers in the facilitation of the introduction of Heritage Studies in Zimbabwe.

In addition, the study established that Heritage Studies as a new learning area was curtailed by an absence of staff development structures as compared to other learning areas like Science, Mathematics and Geography among others. One participant bemoaned, "Heritage Studies is a new learning area and does not have subject panel structures or cluster structures. There were no Heads in Charge, district or cluster structures. Our Heritage group provided a platform which overcame the challenges brought about by the absence of these structures". Hence, we argue from this study that the Heritage Studies WhatsApp group provided structures for staff development. Therefore, we argue that WhatsApp acted as a "vehicle for enhancing teacher professional development" by connecting teachers' networks for professional development as espoused by Zeichner (2003, $p$. 310), Huberman (2001) and Meletiou-Mavrotheris (2012). Subject panel meetings have traditionally been utilised in Zimbabwe to address challenges in the adoption of new learning areas. However, as noted by this study, subject panel meetings were non-existent in the adoption of the Heritage Studies learning area. Hence, teachers were forced by circumstances to utilise their Heritage Studies WhatsApp platform to acquire relevant expertise on the new subject.

Overall, the study also revealed that the Heritage Studies WhatsApp group provided the teachers who participated in this study with a platform for sharing ideas on the new learning area. The majority of participants in the study revealed that they did not have Heritage Studies professional qualifications but were mostly History teachers. While there is evidently an overlap between the two learning areas there was a need for reskilling the History teachers to make them more conversant with Heritage Studies. Thus, the Heritage Studies WhatsApp group provided an opportunity for the teachers to improve their expertise in the learning area through sharing ideas.

However, it was also noted from the study that some teachers on the Heritage Studies WhatsApp platform abused the group to share irrelevant jokes, political news, chain messages and trade union updates. One participant observed, "There are some unscrupulous individuals who abused our Heritage Studies group to share jokes on numerous occasions, which later became a nuisance. It only took the firm hand of the group administrators to nip these deviant characters and bring sanity to the group". While another participant added, "messages demeaning the person of the Education Minister were sometimes shared with the group. However, the group administrator has been vigilant and eliminated the culprits from the group". Thus, we argue that the Heritage Studies WhatsApp group did not only yield positives as negatives were also encountered as revealed by this study in Zimbabwe. In addition, intellectual property rights were also not respected as some reading material was shared without seeking authority from the publishers. Thus, we argue that despite the numerous benefits from the WhatsApp group for the Heritage Studies teachers in Zimbabwe intellectual property rights may have been contravened to a certain extent.

\section{CONCLUSION}

This study on the use of WhatsApp by Heritage Studies teachers in Zimbabwe concludes that WhatsApp can be utilised to facilitate the implementation of the new curriculum in a number of ways. The study established that Heritage Studies teachers used WhatsApp to disseminate the new Heritage Studies syllabus, interpret the new syllabus, share reading material and ideas on the new learning. Therefore, this study concludes that Heritage Studies teachers utilised the WhatsApp platform for staff development. Some challenges encountered by Heritage Studies teachers during the course of the implementation of the new curriculum were addressed through interaction on the WhatsApp platform.

\section{REFERENCES}

Abaido, G., \& El-Messiry, H. (2016). Efficiency of WhatsApp as a Means of Disseminating Educational Information. IT \& Knowledge Excellence , 1-6. Retrieved from http://www.hk5sa.com/icit/5.2 DubaiGhada.pdf

Aldiabat, K. M., \& Navenec, C.-L. Le. (2011). Philosophical Roots of Classical Grounded Theory: Its Foundations in Symbolic Interactionism. The Qualitative Report, 16(4), 1063-1080. Retrieved from http://nsuworks.nova.edu/tqr/vol16/iss $4 / 9$ 
Ali, A. H. (2011). The Power of Social Media in Developing Nations: New Tools for Closing the Global Digital Divide and Beyond. Havard Human Rights Journal, 24(1), 185-219. Retrieved from http://harvardhrj.com/wpcontent/uploads/2009/09/185-220.pdf

Bilbao-Osorio, B., \& Dutta, S. (2012). The Global Information Technology Report 2012: Living in a Hyperconnected World. Geneva.

Bouhnik, D., \& Deshen, M. (2014). WhatsApp Goes to School: Mobile Instant Messaging between Teachers and Students. Journal of Information Technology Education: Research, 13, 217-231. Retrieved from http://www.jite.org/documents/Vol13/JITEv13ResearchP217-231Bouhnik0601.pdf

Cambridge University Press. (2017). Cambridge Online Dictionary. Retrieved May 25, 2017, from dictionary.cambridge.org/dictionary/english/

Chen, P. J. (2013). Social Media. In Australian Politics in a Digital Age (pp. 69-111). ANU Press.

Chiridza, P., Yorodani, J., Sigauke, E., \& Katsaruware, R. D. (2016). Social media and the society: A case study of WhatsApp in Zimbabwe. New Media and Mass Communication, 45(0), 46-50. https://doi.org/10.7176/NMMC.VOL4546-50

Delport, A., \& Makaye, J. (2009). Clustering schools to improve teacher professional development: Lessons learnt from a Zimbabwean case study. Africa Education Review, 6(1), 96-105. https://doi.org/10.1080/18146620902857608

Denzin, N. K., \& Lincoln, Y. S. (2008). The landscape of qualitative research. Los Angeles: Sage Publications.

Dokora, L. D. K. (2015). Update on the Proposed Curriculum Framework for Primary and Secondary Education. Harare.

Gambanga, N. (2016a). Ministry of Education takes unnecessary risks with rushed electronic enrolment system for Form 1. Retrieved December 27, 2016, from http://www.techzim.co.zw/2016/12/ministry-education-takesunnecessary-risk-rushed-electronic-enrolment-system-form-1-places/

Gambanga, N. (2016b, December 28). Zimbabwe registers 793 public WiFi hotspots nationwide led by a Liquid Telecom \&amp; TelOne rollout - Techzim. TechZim. Harare. Retrieved from http://www.techzim.co.zw/2016/12/zimbabwe-registers-793-public-wifi-hotspots-nationwide-led-liquidtelecom-telone-rollout/

Hammersley, M. (2000). Taking sides in social research. London: Routledge.

Haynes, N. (2016). The social media landscape: Performing citizenship online. In Social Media in Northern Chile. UCL Press. Retrieved from http://www.jstor.org/stable/j.ctt1g69xv2.6

Huberman, M. (2001). Networks that alter teaching: conceptualisation, exchanges and experiments. In J. Sole, A. Craft, \& H. Burgess (Eds.), Teacher Development: exploring our own practice. London: Paul Chapman.

ITU. (2016a). ICT Facts and Figures 2016. Geneva. Retrieved from http://www.itu.int/en/ITUD/Statistics/Documents/facts/ICTFactsFigures2016.pdf

ITU. (2016b). Measuring the Information Society Report 2016. Organizacija znanja. Geneva. https://doi.org/10.3359/oz0303157

Kabweza, L. S. M. (2015, February 5). By the numbers: 6 interesting facts about telecoms \&amp; internet in Zimbabwe - Techzim. TechZim. Harare. Retrieved from http://www.techzim.co.zw/2015/02/numbers-6interesting-facts-telecoms-internet-zimbabwe/

Kabweza, L. S. M. (2017, May 8). Econet launches Wi-Fi in kombis - Techzim. TechZim. Harare. Retrieved from http://www.techzim.co.zw/2017/05/econet-launches-wi-fi-kombis/

Mackinnon, G. (2005). Symbolic interactionism: A lens for judging the social constructivist potential of learnercentered chemistry software. International Journal of Technology in Teaching and Learning, 1(2), 89-102.

Maphosa, C., Mutekwe, E., Machingambi, S., Wadesango, N., \& Ndofirepi, A. (2013). School Clusters in Zimbabwe: What Issues Do Clusters Tackle? Int $J$ Edu Sci, 5(3), 293-300. Retrieved from https://www.researchgate.net/profile/Edmore_Mutekwe/publication/270574757_School_Clusters_in_Zimbab we_What_Issues_Do_Clusters_Tackle/links/54ae4e320cf2828b29fcd8a5.pdf ?origin=publication_list

Matseketsa, B. B., \& Mashaah, S. (2017). Heritage Studies Book 1. Harare: Priority Projects Publishers.

Meletiou-Mavrotheris, M. (2012). Online communities of practice as vehicles for teacher professional development. In A. Juan, M. Huertas, S. Trenholm, \& C. Steegmann (Eds.), Teaching mathematics online: Emergent technologies and methodologies (pp. 142-166). Hershey, PA: IGI Global. https://doi.org/10.4018/978-1-60960-875-0.ch007

Murava, P. (2017, February 2). New curriculum: The challenges | Celebrating Being Zimbabwean. The Patriot. Harare. Retrieved from http://www.thepatriot.co.zw/old_posts/new-curriculum-the-challenges/

Mustafa, Z. M., Ghani, Z. A., Zumrah, A. R., Ramly, R. M., Azdi, W. M. F., \& Ahmad, Z. A. (2013). Facebook as Social Media Tools among Muslim Youths in Malaysia. American International Journal of Social Science, 2(8), 173-177. Retrieved from http://www.aijssnet.com/journals/Vol_2_No_8_December_2013/19.pdf

Nadvi, L. (2017). A time of unprecedented Global Change. Durban: UKZ̄NTOUCH.

Nkala, S. (2017). Dokora curriculum review disastrous: Coltart. Retrieved May 3, 2017, from http://www.davidcoltart.com/2017/01/dokora-curriculum-review-disastrous-coltart/ 
Nyandoro, J., Mapfumo, J., \& Makoni, R. (2013). Effectiveness of School Development Committees in Financial Management in Chimanimani West Circuit Primary Schools in Zimbabwe. Social Sciences and Humanities , 4(1), 255-274. Retrieved from www.savap.org.pk

Nziramasanga, C. T. (1999). Zimbabwe: Report of the Presidential Commission of Inquiry into Education and Training: Under the Chairmanship of Dr. C. T. Nziramasanga. Harare.

Oxford University Press. (2017). Oxford Online Dictionary.

Pachikoro Staff. (2016, October 23). The New Curriculum and its implications. Pachikoro. Harare. Retrieved from http://www.pachikoro.co.zw/2016/10/the-new-curriculum-and-its-implications/

Perrin, A. (2015). Social Media Usage: 2005-2015. Retrieved from http://www.pewinternet.org/2015/10/08/2015/Social-Networking-Usage-2005-2015/

Persily, N. (2017). The Modernization Trap The Freedom House Survey for 2016 The End of the Postnational Illusion. Journal of Democracy, 28, 63-76. Retrieved from http://www.journalofdemocracy.org/sites/default/files/07_28.2_Persily \%28web\%29.pdf

Saleem, M., Prot, S., Anderson, C. A., \& Lemieux, A. F. (2015). Exposure to Muslims in Media and Support for Public Policies Harming Muslims. Communication Research, 1-29. https://doi.org/10.1177/0093650215619214

Sayan, H. (2016). AFFECTING HIGHER STUDENTS LEARNING ACTIVITY BY USING WHATSAPP. European Journal of Research and Reflection in Educational Sciences, 4(3). Retrieved from www.idpublications.org

Shabir, G., Mahmood, Y., Hameed, Y., Safdar, G., Farouq, S. M., \& Gilani, S. (2014). The Impact of Social Media on Youth: A Case Study of Bahawalpur City. Asian Journal of Social Sciences \& Humanities, 3(4), 132-151. Retrieved from http://www.ajssh.leena-luna.co.jp/AJSSHPDFs/Vol.3(4)/AJSSH2014(3.4-13).pdf

Sokolova, V. (2013). Social Media in US Presidential Elections 2012: How different use of social media can influence behaviour and participation of the online audience. Uppsala University. Retrieved from http://www.diva-portal.se/smash/get/diva2:668077/FULLTEXT01.pdf

Wangui, J. (2014). Government goes big on Social Media. Nairobi: Business and Tech.

ZBC. (2017). New curriculum will benefit all: Min Dokora. Retrieved June 17, 2017, from http://www.zbc.co.zw/2017/03/13/new-curriculum-will-benefit-all-min-dokora/

Zeichner, K. M. (2003). Teacher research as professional development for P-12 educators in the USA. Educational Action Research, 11(2), 301-326. https://doi.org/10.1080/09650790300200211

Zimbabwe, G. of. (2015). Zimbabwe National Policy for Information and Communication Technology (ICT). Harare.

ZimStat. (2013). Census 2012 National Report. Harare.

Cite this Article: Tarisayi KS and Manhibi R (2017). Social Media Tools in Education: A Case of WhatsApp use by Heritage Studies Teachers in Zimbabwe. Greener Journal of Social Sciences, 7(4): 034-040, http://doi.org/10.15580/GJSS.2017.4.082217108 